\title{
Robert Traba
}

Instytut Studiów Politycznych PAN

ORCID 0000-0002-8229-4342

trabarob@gmail.com

\section{Światy przeżywane (Lebenswelt) polskich robotników przymusowych 1939-1945}

Katarzyna Woniak, Zwangswelten. Emotions- und Alltagsgeschichte polnischer 'Zivilarbeiter' in Berlin 1939-1945, Paderborn: Verlag Ferdinand Schöningh (Brill-Gruppe) 2020 (Reihe: FOKUS. Neue Studien zur Geschichte Polens und Osteuropas, Band 2), Ss. 424.

Bywają tematy historyczne, które w potocznym odbiorze zdają się być bądź wytartymi sloganami, bądź realizacją politycznych projektów. W Polsce często do takiego nurtu należą książki dotyczące II wojny światowej, szczególnie gdy w swoim centrum stawiają Polaków jako ofiary przemocy i eksterminacji okupantów. W międzynarodowym odbiorze wiktymizacja i bohaterskie losy Polaków też nie znajdują większego rezonansu. W obu wypadkach reakcja jest słuszna, bo nie dorobiliśmy się - poza szlachetnymi wyjątkami ${ }^{1}$ - przekonującego nurtu badań, który zajmując się wojennymi losami obywateli polskich, z przekonaniem unikałby pułapek heroizacji i wiktymizacji.

Katarzynie Woniak udało się odejść od takiego schematu. Historyczka i antropolożka, absolwentka UAM i Uniwersytetu w Augsburgu, wieloletnia współpracowniczka

\footnotetext{
1 Niestety autorami prac są głównie autorzy zagraniczni, jak Timothy Snyder, Alexandra Richie, Jochen Böhler, Maren Rögen. Z polskich autorów największy sukces wydawniczy osiągnęła w Niemczech książka Włodzimierza Borodzieja, Geschichte Polens im 20. Jahrhundert, München 2010, wydana w prestiżowej serii wydawnictwa C.H. Beck.
} 
Centrum Badan Historycznych PAN w Berlinie, obecnie zatrudniona w Centrum Studiów Polonoznawczych im. Aleksandra Brücknera w Halle, napisała książkę na pozornie „wytarty” temat, dotyczący losów polskich robotników przymusowych. Sam już jednak tytuł wskazuje, że mamy do czynienia z dziełem nowatorskim: Światy wymuszone. Historia emocji i codzienności polskich robotników w Berlinie w latach 1939-1945. Ponieważ jednak polskie instytucje grantodawcze nie dostrzegły w niej odpowiedniego potencjału, książkę wydała po niemiecku w renomowanym wydawnictwie Schöningha należącego do światowego potentata na rynku książki naukowej - niderlandzkiej korporacji wydawniczej BRILL.

Co jest szczególnego w książce Woniak? Tytułowe „światy wymuszone” to nawiązanie do socjologicznej kategorii Lebenswelt - świat przeżywany, które począwszy od Edmunda Husserla i Jürgena Habermasa zadomowiło się w socjologii fenomenologicznej (Alfred Schütz), a z niej przeszło również na grunt badań historycznych. Przekładając teorię na empirię, chodzi o to, że pojedyncze zdarzenia, których doświadcza człowiek wywołują emocje i stają się częścią jego codzienności. Badamy więc nie tyle same zdarzenia, co skutki, jakie one wywołują w zachowaniach i działaniach ludzi. W przypadku książki Woniak takie podejście owocuje panoramicznym obrazem życia i przeżywania pracy przymusowej w stolicy Niemiec. Możemy się dowiedzieć, jak przebiegał zwykły dzień, zajrzeć do intymnych marzeń, uczuć, tęsknot za rodziną i ziemią rodzinną, potrzebą przeżyć religijnych; możemy poznać cierpienia i rodzące się miłości do współwięźniarek/współwięźniów. Codzienność to jednak nie tylko praca i własne odczuwanie życia, to także relacje do współwięźniów różnych narodowości, różne strategie przeżycia, próby organizowania dywersji czy małego sabotażu. W książce Woniak nie ma nadludzkich bohaterów „walczących za ojczyznę”, a jednocześnie są bohaterowie moralnej postawy w sytuacjach, w których łatwo było ulec presji, np. donosicielstwa oraz pospolitego cwaniactwa kosztem innych. Są w jej opowieści po prostu kobiety i mężczyźni poddani szczególnej próbie w warunkach odosobnienia, strachu i niepewności jutra. Jedni cierpieli, innym udawało się przeżyć bez większego uszczerbku na zdrowiu fizycznym i psychicznym. Wszystkie te zachowania i przeżycia wpisane są w skrupulatnie odtworzone ramy prawno-organizacyjne funkcjonowania nazistowskiej organizacji pracy przymusowej.

Sam problem robotników przymusowych przez lata był niezauważany lub marginalizowany w badaniach. W Polsce pierwsze kompleksowe publikacje, oparte na źródłach Komisji Badania Zbrodni Hitlerowskich, pojawiły się w latach siedemdziesiątych (Czesław Madajczyk, Czesław Łuczak²). Równocześnie rozwijał się nurt badań regionalnych (np. Bohdan Koziełło-Poklewski dla Warmii i Mazur czy Alfred Konieczny dla Śląska ${ }^{3}$ ). Do europejskiego nurtu badań trafiły pod koniec lat dziewięćdziesiątych,

Cz. Madajczyk, Polityka III Rzeszy w okupowanej Polsce, t. 1-2. Państwowe Wydawnictwo Naukowe, Warszawa 1970; Cz. Łuczak, Praca przymusowa Polaków w III Rzeszy, POS, Poznań 1989.

3 B. Koziełło-Poklewski, Zagraniczni robotnicy przymusowi w Prusach Wschodnich $w$ latach II wojny światowej, Państwowe Wydawnictwo Naukowe, Warszawa 1977; A. Konieczny, Zagraniczni robotnicy przymusowi i obozy pracy na Górnym Śląsku w 1944 roku, „Studia Śląskie” 1967, t. 12 , s. $151-220$. 
głównie za sprawą takich badaczy, jak Ulrich Herbert $(1999)^{4}$, Valentina Maria Stefanski ${ }^{5}$ czy Alexander von Plato ${ }^{6}$, później Dieter Pohl ${ }^{7}$ czy w regionalnym wymiarze Annette Schäfer'. Interesujace jest przy tym, że pierwsze impulsy badawcze nie pochodziły ze środowisk uniwersyteckich, lecz z kręgów profesjonalnych badaczy historii lokalnych i aktywistów działań obywatelskich, którzy w latach osiemdziesiątych tworzyli w całych zachodnich Niemczech tzw. ruch warsztatów historycznych (Geschichtswerkstätten).

Skalę zaniedbania i jednocześnie zmiany $\mathrm{w}$ badaniach nad pracą przymusową uświadomiłem sobie w 2007 roku, gdy rozpoczynałem prace nad wystawą o polskich berlińczykach. Wówczas z trudem dotarłem do szacunkowych danych o około 1500 miejscach odosobnienia (obozach) dla robotników przymusowych w Berlinie. Gdy pięć lat później prowadziliśmy z Katarzyną Woniak seminarium na temat nazistowskiej polityki eksterminacyjnej na Freie Universität potwierdzonych było już około 3 tys. obozów. Liczby robotników przymusowych do dzisiaj są dość enigmatyczne, gdyż szacują w samym Berlinie liczbę wszystkich robotników przymusowych na około 300 tys. do 500 tys.. Niewątpliwą rolę w intensyfikacji badań i upamiętnieniu robotników przymusowych odegrało powołanie do życia w 2006 roku berlińskiej dzielnicy Schöneweide Centrum Dokumentacyjnego Nazistowskiej Pracy Przymusowej (Dokumentationszentrum NS-Arbeit). Na terenie państwa niemieckiego i terenach okupowanych na rzecz III Rzeszy pracowało łącznie ponad 26 mln robotników przymusowych, w tym było około 3 mln obywateli polskich.

Liczbę 16 tys. polskich robotników przymusowych w Berlinie Katarzyna Woniak uważa za zdecydowanie zaniżoną, ponieważ nie uwzględnia ona fluktuacji „siły roboczej ze Wschodu" w czasie wojny. Jak autorka odnalazła materiały źródłowe do swojej książki? Odpowiedź na to pytanie jest kolejnym dowodem na niekonwencjonalność badań Katarzyny Woniak, tym razem w warstwie warsztatowej. Podstawowym źródłem są akta sądów różnych instancji (Landes-, Amts- und Sondergerichte), które sądziły robotników narodowości polskiej za setki przeróżnych spraw: od kradzieży chleba, bójki ze współwięźniem po akty świadomego sabotażu. Ilustrują one losy około 3 tys. osób zidentyfikowanych w kartotekach obozowych jako Polacy.

Kto kiedykolwiek pracował z takim materiałem źródłowym, wie jakiego przygotowania warsztatowego wymaga od badaczki jego czytanie i klasyczna krytyka historycz-

U. Herbert, Fremdarbeiter. Politik und Praxis des „Ausländer-Einsatzes “ in der Kriegswirtschaft des Dritten Reiches, Dietz, Berlin-Bonn 1985; idem, Geschichte der Ausländerpolitik in Deutschland. Saisonarbeiter, Zwangsarbeiter, Gastarbeiter, Flüchtlinge, C.H. Beck, München 2001.

5 V.M. Stefanski, Zwangsarbeit in Leverkusen. Polnische Jugendliche im I. G. Farbenwerk, Fibre, Osnabrück 2000.

6 Autor wielu projektów na ten temat, por. A. von Plato, A. Leh i Ch. Thonfeld, Hitlers Sklaven. Internationales lebensgeschichtliches Dokumentationsprojekt zur Sklaven- und Zwangsarbeit, Böhlau, Wien 2008.

7 D. Pohl, T. Sebta (red.), Zwangsarbeit in Hitlers Europa. Besatzung, Arbeit, Folgen, Metropol Verlag, Berlin 2013.

8 A. Schäfer, Zwangsarbeit und NS-Rassenpolitik. Russische und polnische Arbeitskräfte in Württemberg 1939-1945, Kohlhammer, Stuttgart 2000. 
na. Na dodatek nie chodzi tu o kilkanaście czy kilkadziesiąt procesów, lecz o ponad (sic!) 1200. Sam ich przebieg był dość tendencyjny, ale dzięki umiejętnej analizie, czytaniu między wierszami czy wreszcie dzięki odnalezieniu oryginalnej, zarekwirowanej w toku śledztwa korespondencji z rodzinami można było stworzyć tak oryginalne, nowatorskie metodologicznie i źródłowo dzieło. Przy niknącej znajomości języka niemieckiego z pewnością warto byłoby je przetłumaczyć na polski, chyba że dzięki pozycji BRILLA znajdzie się wkrótce wydawca angielski, a my stracimy z horyzontu nie tylko oryginalną badaczkę, ale też inspirujące podejście do jakże „polskiego tematu”. 